\title{
Cement blocks with EVA waste for extensive modular green roof: contribution of components in thermal insulation
}

\section{Blocos cimentícios com resíduos de EVA para telhado verde extensivo modular: contribuição dos componentes no isolamento térmico}

A. B. de MELO

aluisiobmelo@hotmail.com

T. N. M. MENDONÇA ${ }^{b}$ tatyanemartinn@gmail.com

\begin{abstract}
Vegetated roofs can contribute to the quality of the environment in many ways, especially in the reduction of heat transfer to the internal environment of buildings. Among the techniques available to execute this kind of coverage, the use of cemented lightweight blocks is proposed to be compatible with the extensive modular green roof system. For cemented lightweight blocks that are produced with aggregates of EVA (waste from footwear industries), an additional contribution of thermal insulation capacity of the proposed green roof is expected. This article aims to demonstrate such contribution through measurements performed on prototypes in hot and humid weather conditions. After characterizing the thermal insulation capacity of the proposed green roof with reference to different types of conventional coverage, the additional contribution of the component used in this green roof was identified by making comparisons with measurements collected from another green roof that was executed with cement blocks without the presence of EVA aggregates. In these experiments, external and internal surface temperatures were collected in the coverage of each prototype as well as the air temperatures in the external and internal environments. From the analysis of data for a typical summer day, it was possible to confirm that the proposed green roof presented the lowest thermal amplitudes, considering air and surface temperatures. The presence of aggregates of EVA in the proposed blocks contributed to the reduction of internal temperatures.
\end{abstract}

Keywords: extensive green roof, thermal behavior, EVA residue, cement block.

\section{Resumo}

As coberturas vegetadas podem contribuir de várias maneiras na qualidade do meio ambiente, sendo destacada a redução na transferência de calor para os ambientes internos das edificações. Dentre as técnicas disponíveis para execução desse tipo de cobertura propõe-se o uso de blocos cimentícios leves compatíveis com o sistema de telhado verde extensivo modular. Para os blocos cimentícios leves, produzidos com agregados de EVA (resíduos da indústria de calçados), espera-se uma contribuição adicional na capacidade de isolamento térmico do telhado verde proposto. No presente artigo, pretende-se demonstrar tal contribuição, através de medições realizadas em protótipos na condição de clima quente e úmido. Após caracterizar a capacidade de isolamento térmico do telhado verde proposto, tendo como referência diferentes tipos de coberturas convencionais, foi identificada a contribuição adicional do componente utilizado nesse telhado verde, fazendo comparações com medições coletadas em outro telhado verde, executado com blocos cimentícios sem a presença dos agregados de EVA. Nos experimentos, foram coletadas temperaturas superficiais externas e internas em cada cobertura dos protótipos, bem como as temperaturas do ar nos ambientes externo e interno. A partir da análise dos dados para o dia típico de verão foi possível confirmar que o telhado verde proposto apresentou as mais baixas amplitudes térmicas, considerando as temperaturas do ar e superficiais internas. A presença dos agregados de EVA nos blocos propostos contribuiu na redução das temperaturas internas.

Palavras-chave: telhado verde extensivo, comportamento térmico, resíduo de EVA, bloco cimentício.

Universidade Federal da Paraíba, Departamento de Arquitetura

e Urbanismo, Centro de Tecnologia, João Pessoa - PB, Brasil;

Universidade Federal da Paraíba, Programa de Pós-Graduação em Engenharia Civil e Ambiental, Centro de Tecnologia, João Pessoa - PB, Brasil. 


\section{Introduction}

The proposals that aim for the reduction of the energy consumption in the built environment are more and more necessary, with the upmost of importance in the development of alternatives which use technologies that reduce the demand for energy in the buildings. From that perspective, the green roofs in the buildings have been manifesting not only as an effective alternative for the reduction of the energy consumption in the buildings (BERARDI et al. [1]) for the cooling of hot weather indoor environments, but also in many aspects related to the environmental sustainability. For example, in the review of the state of the art about the green roofs theme (BERARDI et al. [1]) it is noticed that they can contribute to reduce the urban heat islands, to mitigate the air pollution, to decrease the flux of pluvial water in the urban drainage systems, to lessen the noises and to increase the biodiversity, amongst other things.

In regards to the classification of the green roofs, the main consolidated attributes in the literature (BERARDI et al. [1]) are featured for the extensive type, which corresponds to the lightest system, with maximum overload limited to $150 \mathrm{~kg} / \mathrm{m}^{2}$, which uses small plants and has a facilitated construction process as well as simplified maintenance, with little need for irrigation, having a low execution cost.

As for the materials used in the development of the green roofs the highlight is that they are coherent with the proposal of environmental sustainability. So, according to Bianchini and Hewage [2] although it is considered a benefit to install green roofs with polymeric materials, in order for this type of covering to be considered environmentally adequate, the use of recycled materials that generate little waste and few pollutants in its fabrication process must be prioritized, and it also has to require little energy.

In fact, from this perspective, the use of light concrete with waste from the footwear industry (Ethylene-vinyl acetate - EVA) to produce modules to execute the system of modular extensive green roof seems to be aligned with this discussion. In this sense, it has to be highlighted that the potential for environmental valuation of the product must be assessed, including the identification of its

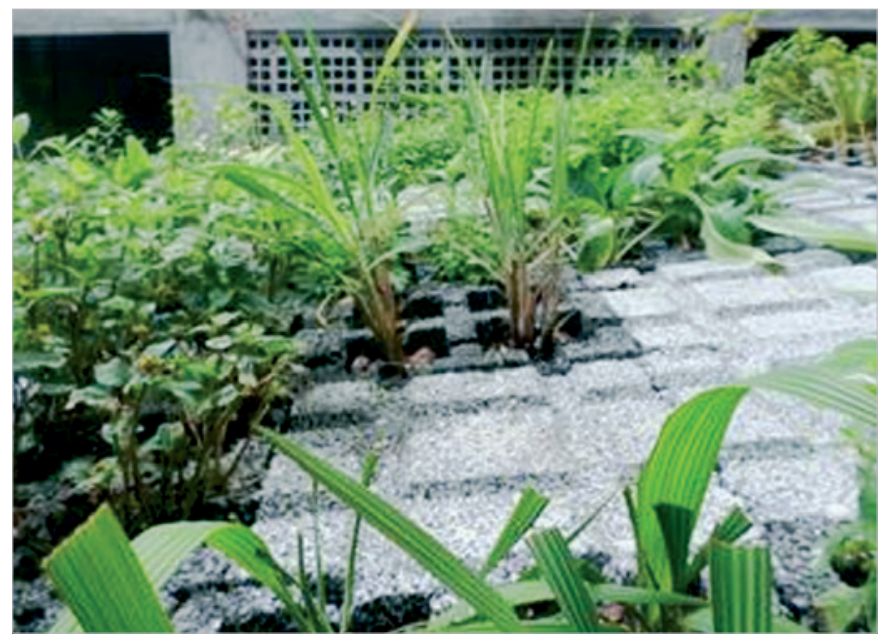

possible contributions for the improvement of the quality of the built environment. The possibility of consolidating the cited modules as an alternative for the adequate destination of the EVA waste must also be seen as an important contribution to decrease the environmental problems, caused by its increasing volumes of disposal generated in footwear industry regions.

It is known that the Ethylene-vinyl acetate (EVA) is a copolymer which is used a lot in the footwear industry for the confection of expanded sheets, which are later cut into insole shapes and midsoles, a moment when a great amount of waste is produced. This kind of waste, generated by the footwear industry, according to studies performed in the south of Brazil, came to over 200 tons per month in 2001, the largest volume resulting from the cuts of expanded sheets to produce the footwear (ZATTERA et al. [3]). This waste has been investigated (GARLET [4]) with the purpose of evaluating its potential for recycling as an aggregate for the production of light concrete, having many possibilities of applications in various constructive subsystems been explored, such as elements of vertical sealing, the filling of depressed slabs, floating floors, etc. (BEZERRA [5]; HAX [6], POLARI FILHO [7]; ROCHA [8]; MELO e LIMA FILHO [9], SANTOS [10]; TUTIKAN et al. [11]). In Paraíba, the footwear industry, which has significant economic power in the state, produces great amounts of waste annually, pieces which cannot be totally re-used by the industry itself. Among the waste, Ethylene-vinyl acetate (EVA) sheets remains are notable. Because of how difficult it is to store the whole volume of residual EVA, some industries have been sending their waste to cement industries based in the region, which use it as fuel for their kilns in the production of clinker.

The proposal of recycling the EVA waste into cement blocks as an applicable technology in the execution of the extensive modular green roof allows many environmental gains in different scales. In the city scale, beyond the reduction of environmental impacts, by making the alternative destination of the type of industrial waste in question feasible, there is a possibility of aggregating the ample benefits to the urban environment in its climatic, hydrological, etc. aspects, considering that it is possible to favor the dissemination

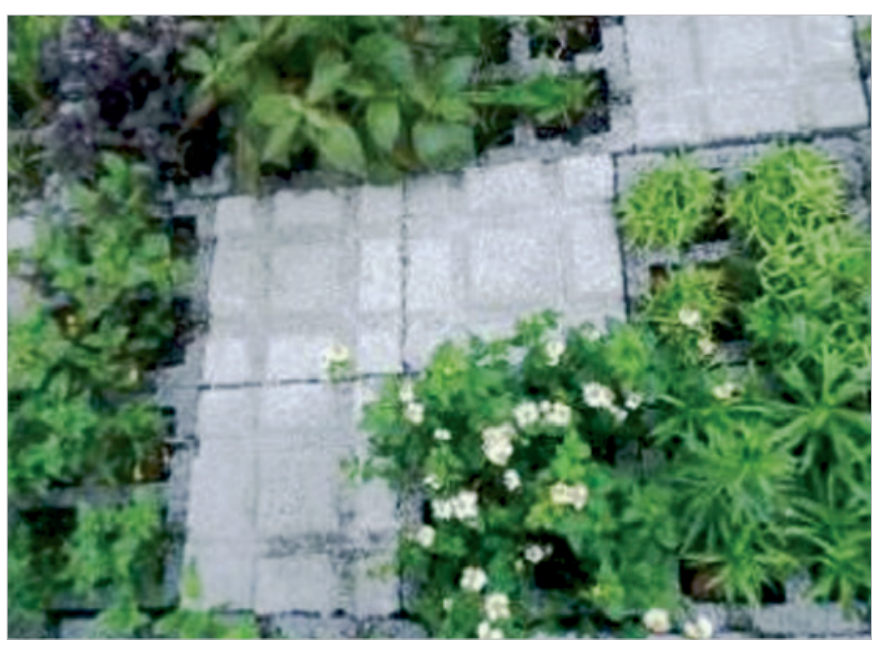

Figure 1

Extensive modular green roof proposed with TEVA blocks (partially vegetated areas) 
of the adoption of green roofs for the buildings in the urban space, based on a proposal that shows easy execution and maintenance. In the building scale, there is the possibility of adding benefits brought by the green roofs, due to the use of EVA waste, which are transformed into light aggregates, from which additional contributions in the reduction of heat flux through the coverings are expected, for example.

In this sense, while it is necessary to encourage the use of new techniques in the building processes that minimize the consequences of anthropic activities, it is important that the ideas be enhanced, seeking to characterize the performance of the proposed systems. Thus, this article presents the results of an experimental study, which proposes the use of pre-molded light cement blocks with EVA waste (here named TEVA blocks), compatible with the system of extensive modular green roof, seeking to evaluate the additional contribution of the components for the thermal insulation of the green roof under analysis. In this case, it is aimed to innovate the geometry of the proposed pre-molded block, making it versatile when it comes to its usage for the execution of the green roof, with the same component being used at times to receive vegetation, at other times to serve as a floor, when placed in an inverted position (Figure 1). This idea aims to enable the composition of green roofs that facilitate the visitation and maintenance of the plants, with areas which are partially covered with vegetation beside paved areas.

In the proposal of green roofs it is important to consider that the materials that compose them also have an influence in the thermal behavior, affecting different thermo-physical properties of the covering system under analysis.

In the study presented in this article it is aimed to control some of the variables involved, when evaluations of the results obtained from prototypes that have been built in the same way, with the same materials, but different coverings over the pre-molded slab are made. So, initially, it is aimed to characterize the capacity of thermal insulation of the proposed green roof with the TEVA blocks, with the performance of different types of conventional coverings as a reference. After that, in order to meet the goal of the study, an identification of the additional contribution of the TEVA block (with EVA aggregates) present in the green roof is sought, by comparing its results to measurements collected from another green roof, executed with the same type of vegetation on cement blocks (concrete blocks), without the presence of the EVA aggregates.

During this process, the experiments were performed in the same climatic conditions, with simultaneous measurements for every two prototypes that were compared, one of them always with a green roof with TEVA blocks. Therefore, in the initial stage of the study, it is known that the green covering has, in fact, a lower thermal transmittance than the conventional coverings used as a reference in this study, with its interest only to characterize the capacity of insulation of the proposed green roof with TEVA blocks, in relation to the thermal behavior of the conventional roofs.

\section{Efficiency of the green roof in controlling the temperatures}

According to Castleton et al. [12] the green roofs are efficient in the reduction of the internal temperature, with positive impacts in the decrease of the heating during the winter and cooling during the summer, consequently with the reduction of the annual energy consumption of the building. The impact of the green roof on the air temperature in the internal environment is more significant in hot climates (JAFFAL et al. [13]). For example, the effect of the green roof on the decrease of the internal air temperature was observed (JAFFAL et al. [13]), during the summer time, at 2,6 ${ }^{\circ} \mathrm{C}$ and $1,4^{\circ} \mathrm{C}$ for buildings in the cities of Athens (Greece) and Stockholm (Sweden) respectively, which represent different European climates (Mediterranean climate for Athens and Cold climate for Stockholm).

In fact, the well projected and managed green roof can be considered an efficient thermal insulator during the summer, reducing the heat flux through the covering. In this analysis (DEL BARRIO [14]), attention is drawn to the positive effects of the shadowing of the foliage, indicating that it is important to give preference to plants with large leaves and with horizontal development; as well as the influence of the thickness of the substrate (ground), of its apparent density and also the level of humidity in the ground itself.

In the study developed (OULDBOUKHITINE et al. [15]), comparing the experimental records with the numerical results, it was sought to validate the proposed model to evaluate the impact of the green roof on the energetic performance of the buildings. The experimental data was collected from prototypes in the University of La Rochelle (France), with rectangular form on a floor plan, without windows and with façades painted in white. For the measurement of the surface temperatures, thermocouples installed on the covering of the prototypes were used, which, for the green roof, were placed on the foliage; on the interface between the vegetation base and the ground; and on the interface between the ground and the support structure (concrete slab) of the green roof. A meteorological station installed next to the prototypes registered the climatic data in the place. The numerical and experimental data for the temperature did not differ more than $2{ }^{\circ} \mathrm{C}$, for a confrontation of 7 days records. From the results obtained (OULDBOUKHITINE et al. [15]), the contribution of the density of the foliage for the thermal behavior of the green roof was highlighted, evidencing that the use of vegetation on the covering of buildings improves both the thermic comfort and the energetic performance of the buildings. The authors also highlighted the benefits of the green roof when compared to the concrete slab that is exposed to the solar irradiance, for the summer time, due to the significant decrease of the outside surface temperature of the structure of support of the green roof. As a matter of fact, this temperature remained lower when compared to the outside air temperature, for a typical summer day, which is justified by the effect of the transpiration and shadowing of the foliage.

In an experiment (VECCHIA [16]) performed with prototypes in fullscale, built in São Carlos/SP (Brazil), adopting the typical experimental day $($ Oct 9,2004$)$ hotter and drier (highest outside air temperature $=34.04{ }^{\circ} \mathrm{C}$; temperature range of $21.07^{\circ} \mathrm{C}$ ), from a series of 7 days of continuous measurements, the thermal behavior of a system of light green covering (executed on a pre-molded concrete slab) was evaluated, compared to traditional covering systems without thermal insulation, executed with 3 different types of roof tiles (ceramics, galvanized steel and corrugated fiber-cement) supported by wooden 
structures. Additionally, a comparison was made between the system of light green covering and a covering executed with pre-molded concrete slab (with the application of white waterproof coating), exposed to insolation. From the results (VECCHIA [16]) the capacity of the light green covering, among the other systems which were compared, of controlling the internal temperatures of the prototype, reducing the difference between the highest and the lowest values was confirmed. This was noticeable for the surface temperature of the roof, as well as for the internal air temperature of the prototype with the green roof, presenting the lowest temperature range, $9.2^{\circ} \mathrm{C}$ and $12.6^{\circ} \mathrm{C}$ respectively. Only with the green covering, the highest internal surface temperature of the roof of the prototype remained lower $\left(26.7{ }^{\circ} \mathrm{C}\right)$ and $2.1^{\circ} \mathrm{C}$ below the highest inside air temperature (and only in this case it was inferior to $30^{\circ} \mathrm{C}$ ). The green covering enabled a thermal delay of 4 hours in the relation between the inside and outside air temperatures.

In another study (ANDRADE e RORIZ [17]) performed in the city of São Carlos/SP, the records of inside surface temperatures of the covering (conventional pre-molded concrete slab) of an existing building with two areas were evaluated. One of the areas had a green roof (with grass) and the other had its slab directly exposed to the sun. The records corresponded to two different periods winter and summer. The vertical sealing of one of the façades that corresponded to both areas of this building was made with hollow blocks. The results (ANDRADE e RORIZ [17]) proved that the lowest surface temperatures on the internal faces of the slab were always lower (during both summer and winter) for the covering with exposed slab with the highest temperature range $\left(19.4{ }^{\circ} \mathrm{C}\right)$ recorded during summer. On the other hand, the highest surface temperatures on the internal faces of the slab under the green roof were always lower $\left(23.2^{\circ} \mathrm{C}\right)$, with fewer daily oscillations (temperature range of only $\left.1.1^{\circ} \mathrm{C}\right)$, during summer, when the highest difference $\left(16{ }^{\circ} \mathrm{C}\right)$ was verified between the highest temperatures for both coverings. Such differences were associated with the shading, the higher thermal inertia and with the evaporative cooling, all enabled by the green roof.

In a previous study (MORAIS [18]), performed on this same prototype, it was observed that the inside air temperature in the areas evaluated (comparison between the exposed slab and the green roofing) were very different, with the biggest difference between the highest air temperatures in each area reaching $3.8^{\circ} \mathrm{C}$, recorded during summer time. The biggest difference $\left(25.1^{\circ} \mathrm{C}\right)$ between the highest interior surface temperatures on the roof, comparing both areas with different coverings, was recorded during summer. Considering the values obtained (MORAIS [18]), due to the comparisons made, a more satisfactory performance for the green covering was verified, which remained stable and with fewer daily thermal fluctuations, both during winter and during summer. Thus, it was concluded that the vegetated roofing has a potential for application in the considered climate (São Carlos/SP) in order to improve the energy efficiency of the buildings.

\section{Methodology}

In the study performed, it was aimed to, initially, characterize the differences in thermal behavior between the proposed green roof with TEVA blocks and 3 (three) types of conventional coverings, often found in popular habitations of lower standards. Next, an attempt was made to identify the difference in thermal behavior between both extensive modular green roofs, executed with concrete blocks and TEVA blocks, respectively. In this case, both pre-molded blocks are made of cement, have the same geometry, with the only difference being the presence of light aggregates (EVA waste) in the TEVA blocks, as a partial substitution of the natural aggregates. The experiments were performed in the city of João Pessoa/ PB (Brazil), characterized by a hot and humid climate, with the use of five prototypes (test cells), which received different coverings and were built in a chosen area with few nearby buildings (Figure 2), whose geographic coordinates are: $7^{\circ} 9^{\prime} 58^{\prime \prime} S$; $34^{\circ} 48^{\prime} 58^{\prime \prime} W$. For the experiment purposes, both blocks (TEVA and concrete) received the same type of medicinal vegetation, the Mexican mint (Figures $2 \mathrm{~b}$ and $02 \mathrm{c}$ ).

All five prototypes have the same solar orientation, same dimensions (on floor plan: $1.0 \mathrm{~m} \times 1.0 \mathrm{~m}$, internally), with distances of $2.7 \mathrm{~m}$ between them, being built with the same type of masonry in ceramic brick ( 8 holes) and cement mortar coating on both sides. The inside floorings are cemented and the slabs are pre-molded and conventional (with the use of small beams, ceramic blocks and

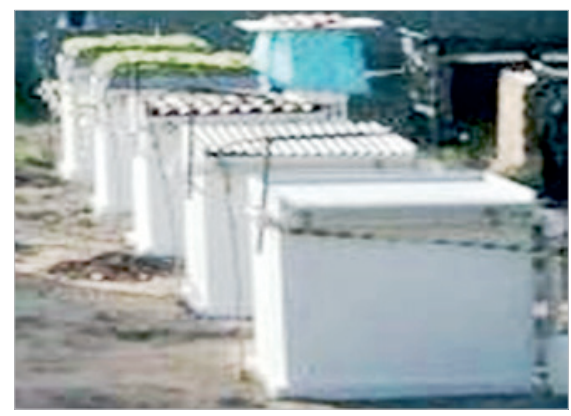

overview of prototypes with five different covers

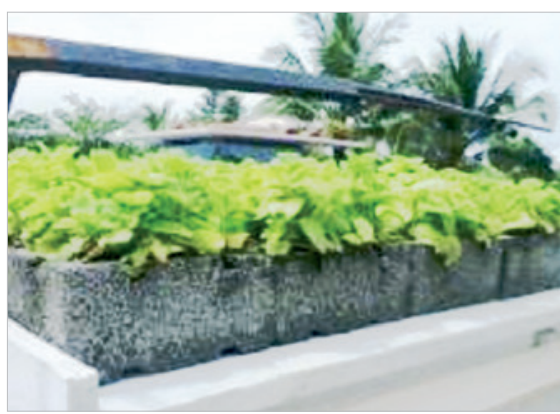

B ail of prototype with green roof with TEVA blocks on the slab

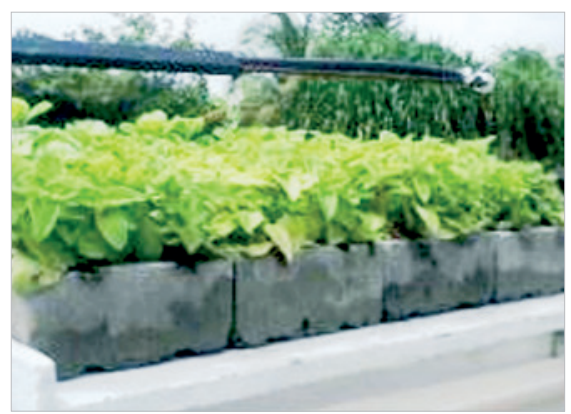

C detail of prototype with green roof with concrete blocks on the slab

Figure 2

Prototypes built in area with few nearby buildings 


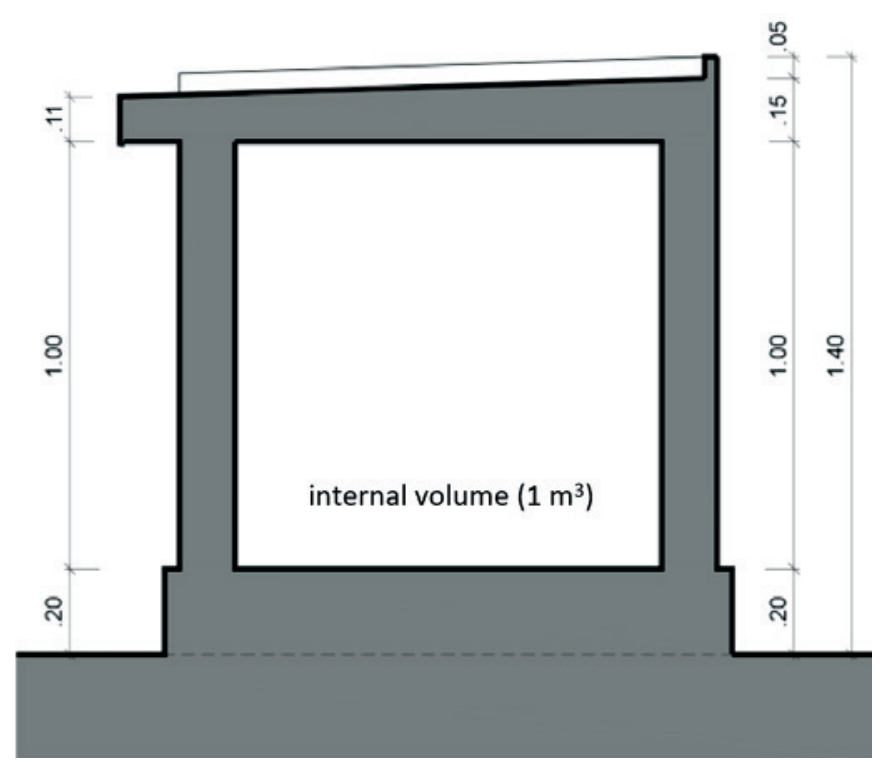

Figure 3

Section of the prototype (test cell)

a $4 \mathrm{~cm}$ concrete layer), cement mortar coated on both internal and external sides and waterproofed on the outside with white acrylic paint. The masonry (internal and external sides) received a calcium oxide paint (in white) finishing, as did the interior face of the slab. No ventilation in the inside of the prototypes was allowed during the measurements. The internal volume of the test cells is $1.0 \mathrm{~m}^{3}$ (Figure 3), with that being the only difference in regards to the coverings placed on each slab.

The TEVA block (Figure 4) was produced with cementitious composite with a 1:5 dosage (cement: aggregates; by volume), using a proportion of $90 \%$ EVA and $10 \%$ sand among the aggregates. In this case, only the green roof proposed with TEVA blocks fits into the category of extensive, with maximum overload of 150 $\mathrm{kg} / \mathrm{m}^{2}$ on the slab, which is the limit value for the category.

The measurements of the internal and external surface temper- atures of each prototype's covering were performed during the period between December 29, 2014 and January 24, 2015, summer time in the region, when the typical summer days take place. During this period, the air temperatures in the inside and outside areas of each prototype were also registered. For every 6 days of data collection, considering the simultaneous measurements for every 2 prototypes (one of them always with a green roof with TEVA blocks), only one (1) typical summer day was selected for the analysis, whose selection took into account the records for the following climatic elements: air temperature, relative air humidity and precipitation (rainfall). The following equipment and measuring gadgets were used:

\section{a) Outside the prototypes}

Weather station (Davis wireless Vantage Pro2TM) to record the air temperature, relative air humidity, rainfall data, solar irradiation data, etc., was installed in an area close to the prototypes.

\section{b) In the prototypes}

Onset brand Data loggers, which store air temperature and relative air humidity data, were placed on the geometric center of the inside of each prototype. (Figure 5)

- Thermocouples (type "T", composed by copper wire $(+)$ and constantan (-) with a sheath and plastic insulator) were installed on the internal and external surfaces of the prototypes' roofs, connected to the data acquisition system (DAQ), Universal Quantum X, which has eight reception channels set to record the temperature every second. For the comparative analysis for each pair of prototypes with different types of roofing, the thermocouples were placed on the central points of the roof. Over each thermocouple, small foam cores were placed so that the obtained records favored the measurements with interest, whichever the temperature ranges caused by the direct contact with the internal and external surfaces of the roofs are. In the case of outside surface temperatures in the prototypes with green roofs it was considered that the vegetation itself would re-

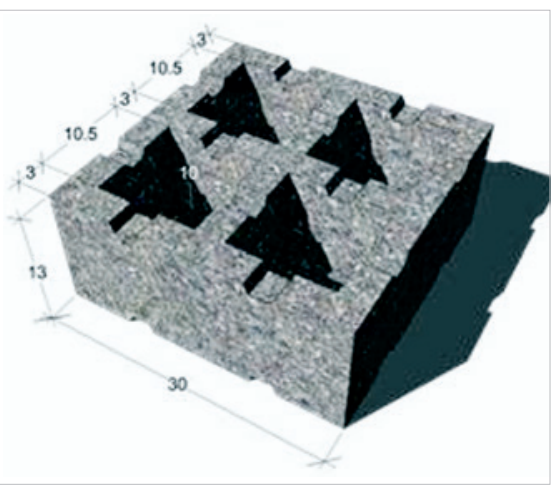

TEVA block dimensions (cm)

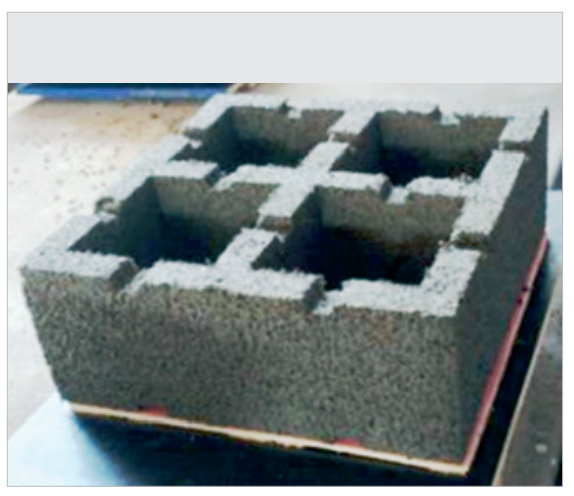

B TEVA block molded

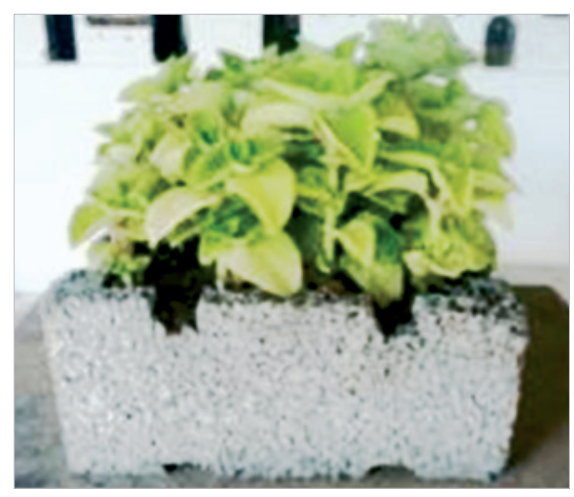

TEVA block vegetated

Figure 4

Proposed TEVA block to execute the extensive modular green roof 
place the foam cores, as the thermocouple placed on the ground (Figure 5) was shaded by the foliage. For the conventional prototypes, the thermocouples for the record of outside surface temperatures were placed on the roof tiles (ceramics or fiber-cement) and on the exposed slab, being shaded by the small foam cores.

The procedures adopted had the studied performed by Ouldboukhitine et al. [15]; Vecchia [16]; Andrade e Roriz [17] e Morais [18] as a reference.

The data collected was systematized in tables and graphs, considering initially the records for internal and external air temperature of the prototypes, for six (6) days of measurements. Next, the typical summer day for the period of measurements was identified, which was used to analyse the thermal behavior of the prototypes that were compared. The identification of the typical summer day had the value of $30.9{ }^{\circ} \mathrm{C}$ as a reference for the highest daily temperature, indicated on Table A2 of the NBR 15575-1 [19], corresponding to the city of João Pessoa-PB (Brazil), which is the place where the experiments were performed (in this Table there is also reference of daily temperature range of $6.1{ }^{\circ} \mathrm{C}$ for the same city). In this case it was also considered that the day chosen should be preceded by at least another day with similar characteristics, preferably without the occurrence of precipitation (rainfall).

On the second moment of analysis, considering the records for the typical summer day only, all of the records of temperature for each pair of prototypes simultaneously evaluated were presented on the same graph, enabling the verification of the differences in behavior due to internal and external air temperatures, as well as internal and external surface air temperatures in the respec-

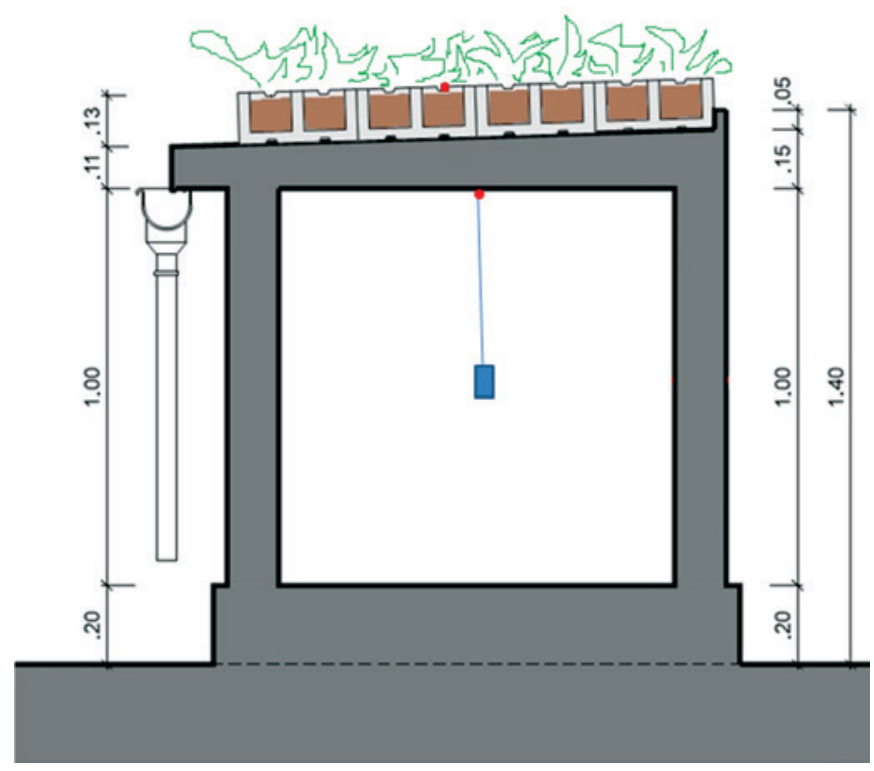

\section{Figure 5}

Positioning of the Datalogger (geometric center of the internal space) and of the thermocouples on the surfaces of the internal and external sides of the prototypes' covers (red points)

tive coverings. As a complement to this analysis, the temperature ranges for the surface temperatures on the roof were discussed, considering the internal and external spaces of the prototypes.

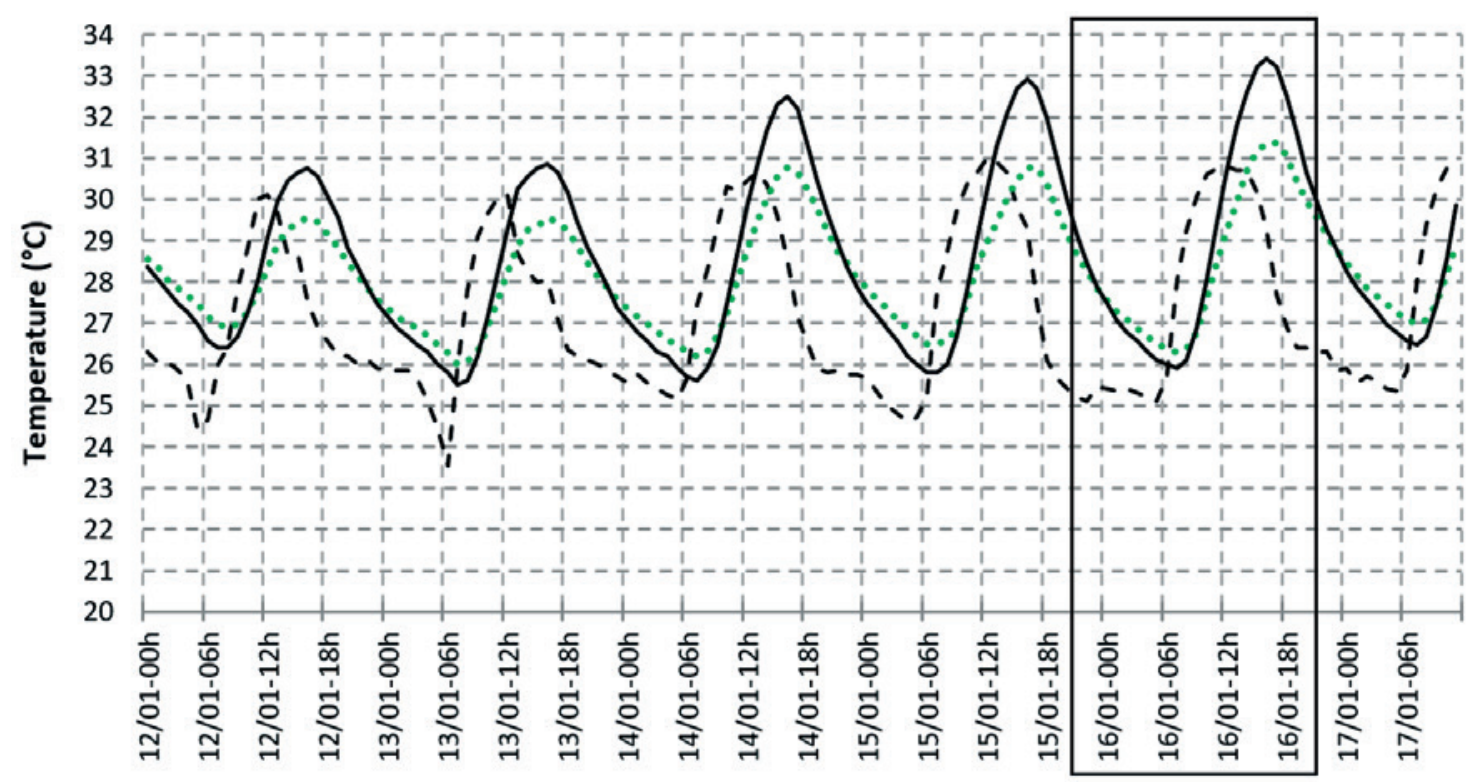

Date - time

- - - Ext. Air Temp.

- Int. Air Temp. (TEVA block)

Int. Air Temp. (exposed slab)

Figure 6

Records for the prototypes with exposed slab and with green roof with TEVA blocks 
Cement blocks with EVA waste for extensive modular green roof: contribution of components in thermal insulation

\section{Table 1}

Climatic elements in the prototypes' external environment, used to select the typical summer days (in bold and grey background)

\begin{tabular}{|c|c|c|c|c|c|c|c|}
\hline \multirow[t]{2}{*}{ Prototypes } & \multirow[t]{2}{*}{ Climatic elements } & \multicolumn{6}{|c|}{ Dates (month-day) } \\
\hline & & Jan-12 & Jan-13 & Jan-14 & Jan-15 & Jan-16 & Jan-17 \\
\hline \multirow{8}{*}{$\begin{array}{c}\text { Exposed slab } \\
\text { X } \\
\text { extensive } \\
\text { modular green } \\
\text { roof TEVA blocks }\end{array}$} & Air temperature maximum $\left({ }^{\circ} \mathrm{C}\right)$ & 30,6 & 30,1 & 31,0 & 31,1 & 30,8 & 31,3 \\
\hline & Daily temperature range $\left({ }^{\circ} \mathrm{C}\right)$ & 6,3 & 6,8 & 5,5 & 6,6 & 5,7 & 6,7 \\
\hline & Air temperature minimal $\left({ }^{\circ} \mathrm{C}\right)$ & 24,3 & 23,3 & 25,1 & 24,5 & 25,1 & 24,6 \\
\hline & Relative air humidity max. (\%) & 94 & 93 & 83 & 84 & 84 & 94 \\
\hline & Relative air humidity min.(\%) & 72 & 69 & 65 & 62 & 64 & 67 \\
\hline & Precipitation - rainfall (mm) & 5,0 & 1,4 & 0,0 & 0,0 & 0,0 & 12,0 \\
\hline & Solar radiation peak $\left(\mathrm{W} / \mathrm{m}^{2}\right)$ & 1.050 & 1.083 & 1.059 & 1.029 & 1.056 & 1.060 \\
\hline & Global daily solar rad. $\left(\mathrm{W} / \mathrm{m}^{2}\right)$ & 238,73 & 258,13 & 300,27 & 308,98 & 317,23 & 270,98 \\
\hline
\end{tabular}

\begin{tabular}{|c|c|c|c|c|c|c|c|}
\hline \multirow[t]{2}{*}{ Prototypes } & \multirow[t]{2}{*}{ Climatic elements } & \multicolumn{6}{|c|}{ Dates (month-day) } \\
\hline & & Jan-05 & Jan-06 & Jan-07 & Jan-08 & Jan-09 & Jan-10 \\
\hline \multirow{8}{*}{$\begin{array}{c}\text { fiber-cement roof } \\
\text { tiles } \\
\text { X } \\
\text { extensive } \\
\text { modular green } \\
\text { roof TEVA blocks }\end{array}$} & Air temperature maximum $\left({ }^{\circ} \mathrm{C}\right)$ & 30,5 & 30,8 & 30,7 & 30,6 & 30,4 & 30,7 \\
\hline & Daily temperature range $\left({ }^{\circ} \mathrm{C}\right)$ & 4,9 & 5,6 & 5,9 & 5,1 & 5,6 & 5,5 \\
\hline & Air temperature minimal $\left({ }^{\circ} \mathrm{C}\right)$ & 25,6 & 25,2 & 24,8 & 25,5 & 24,8 & 25,2 \\
\hline & Relative air humidity max. (\%) & 85 & 88 & 90 & 89 & 86 & 85 \\
\hline & Relative air humidity min.(\%) & 67 & 66 & 63 & 63 & 66 & 66 \\
\hline & Precipitation - rainfall (mm) & 0,0 & 0,0 & 0,4 & 1,8 & 0,4 & 0,8 \\
\hline & Solar radiation peak $\left(\mathrm{W} / \mathrm{m}^{2}\right)$ & 1.054 & 1.104 & 1.094 & 972 & 1.077 & 1.139 \\
\hline & Global daily solar rad. $\left(\mathrm{W} / \mathrm{m}^{2}\right)$ & 296,90 & 287,15 & 249,81 & 256,98 & 282,25 & 285,17 \\
\hline
\end{tabular}

\begin{tabular}{|c|c|c|c|c|c|c|c|}
\hline \multirow[t]{2}{*}{ Prototypes } & \multirow[t]{2}{*}{ Climatic elements } & \multicolumn{6}{|c|}{ Dates (month-day) } \\
\hline & & Dec-29 & Dec-30 & Dec-31 & Jan-01 & Jan-02 & Jan-03 \\
\hline \multirow{8}{*}{$\begin{array}{c}\text { ceramic roof tiles } \\
\text { X } \\
\text { extensive } \\
\text { modular green } \\
\text { roof TEVA blocks }\end{array}$} & Air temperature maximum $\left({ }^{\circ} \mathrm{C}\right)$ & 30,6 & 30,9 & 30,5 & 31,2 & 26,8 & 30,2 \\
\hline & Daily temperature range $\left({ }^{\circ} \mathrm{C}\right)$ & 6,2 & 7,6 & 5,3 & 7,8 & 4,2 & 8,8 \\
\hline & Air temperature minimal $\left({ }^{\circ} \mathrm{C}\right)$ & 24,4 & 23,3 & 25,2 & 23,4 & 22,6 & 21,4 \\
\hline & Relative air humidity max. (\%) & 85 & 92 & 87 & 94 & 97 & 97 \\
\hline & Relative air humidity min.(\%) & 63 & 64 & 68 & 62 & 83 & 67 \\
\hline & Precipitation - rainfall (mm) & 0,2 & 0,0 & 0,0 & 4,6 & 22,2 & 0,2 \\
\hline & Solar radiation peak $\left(\mathrm{W} / \mathrm{m}^{2}\right)$ & 995 & 960 & 988 & 788 & 640 & 1.104 \\
\hline & Global daily solar rad. $\left(\mathrm{W} / \mathrm{m}^{2}\right)$ & 304,77 & 274,31 & 216,00 & 189,21 & 134,65 & 316,75 \\
\hline
\end{tabular}

\begin{tabular}{|c|c|c|c|c|c|c|c|}
\hline \multirow[t]{2}{*}{ Prototypes } & \multirow[t]{2}{*}{ Climatic elements } & \multicolumn{6}{|c|}{ Dates (month-day) } \\
\hline & & Jan-19 & Jan-20 & Jan-21 & Jan-22 & Jan-23 & Jan-24 \\
\hline \multirow{8}{*}{$\begin{array}{c}\text { extensive } \\
\text { modular green } \\
\text { roof concrete } \\
\text { blocks } \\
X \\
\text { extensive } \\
\text { modular green } \\
\text { roof TEVA blocks }\end{array}$} & Air temperature maximum $\left({ }^{\circ} \mathrm{C}\right)$ & 30,7 & 31,1 & 31,4 & 31,3 & 31,4 & 31,1 \\
\hline & Daily temperature range $\left({ }^{\circ} \mathrm{C}\right)$ & 5,6 & 6,3 & 5,4 & 6,2 & 6,1 & 5,8 \\
\hline & Air temperature minimal $\left({ }^{\circ} \mathrm{C}\right)$ & 25,1 & 24,8 & 26,0 & 25,1 & 25,3 & 25,3 \\
\hline & Relative air humidity max. (\%) & 89 & 85 & 86 & 85 & 87 & 87 \\
\hline & Relative air humidity min.(\%) & 70 & 65 & 66 & 65 & 64 & 67 \\
\hline & Precipitation - rainfall (mm) & 0,2 & 0,2 & 0,0 & 0,2 & 0,0 & 0,0 \\
\hline & Solar radiation peak $\left(\mathrm{W} / \mathrm{m}^{2}\right)$ & 1.086 & 1.060 & 1.109 & 1.051 & 1.072 & 1.021 \\
\hline & Global daily solar rad. (W/m²) & 309,48 & 368,39 & 283,29 & 299,94 & 283,29 & 233,25 \\
\hline
\end{tabular}




\section{Results and discussions}

In order to characterize the thermal behavior of the green roof proposed with TEVA blocks, the results are analyzed according to the collection of simultaneous records in each two types of covering executed on the prototypes. Initially, the data collected with the green roof with TEVA blocks related to each type of conventional covering is confronted. In the case of the comparison between both green roofs (with concrete blocks and with TEVA blocks) performed afterwards, there is the possibility of identifying the additional contribution of the EVA aggregates (waste from the footwear industry) in the effects of the green roof for the expected improvement of the thermal behavior in the interior of the prototype.

Table 1 presents some climatic elements extracted from data which was recorded by the weather station. Based on the records from the exterior of the prototypes, such as air temperature, relative air humidity and precipitation (rainfall), during the period of measurements, 6 (six) continuous days, the identification of the typical summer days used in each case was made, according to the pairs of coverings under analysis.

Some characteristics of the local climate can be highlighted from the data presented on Table 1, especially for the typical summer days that were selected, to which there is little variation regarding the temperature range (between $5.3^{\circ} \mathrm{C}$ and $5.7^{\circ} \mathrm{C}$ ), the relative air humidity (for the highest, there is a variation between $84 \%$ and 88 $\%$; for the lowest, there is a variation between $64 \%$ and $68 \%$ ) and the highest air temperature (between $30.5^{\circ} \mathrm{C}$ and $31.4^{\circ} \mathrm{C}$ ).

\subsection{Characterization of the thermal behavior of the Green Roof with TEVA blocks}

\subsubsection{Regarding the covering with exposed slab}

On the typical summer day that was chosen (January 16, 2015) for the analysis of the records with both prototypes, with exposed slab and with the green roof with TEVA blocks, it can be observed that the highest internal temperature of the prototype with the green roof with TEVA blocks is close to the highest external temperature (Figure 6). This same observation for this prototype can be applied for other days of the week of measurements, with days when the highest internal air temperature was lower than the highest external air temperature even. This same behavior does not apply to the prototype with exposed slab, which always presents a more elevated $\left(2^{\circ} \mathrm{C}\right)$ highest air temperature in the internal environment, with a higher temperature range (approximately $7.5^{\circ} \mathrm{C}$ ). This result is consistent to the ones achieved in similar studies (MORAIS [18]; JAFFAL [13]) which characterized the reduction of the highest internal air temperature in the areas with green roofs, reaching 3.8 ${ }^{\circ} \mathrm{C}$ and $2.6{ }^{\circ} \mathrm{C}$, for the measurements during summer time, in São Carlos-PB-Brazil and Athens-Greece, respectively.

In the present study, the thermal behavior of the prototype with exposed slab with little damping of the heat flux during the day through its covering is confirmed, although it has high reflectance for being painted in white. Nevertheless, the thermal delay between the highest air temperatures (internal and external) of the prototype, of approximately 5 hours is practically the same for both types of coverings compared.

In Figure 7, it is possible to see the records of the air temperatures (internal and external) and surface temperatures (internal and external) for the typical summer day. The reduction of the highest surface temperature on the internal face of the roof $\left(30^{\circ} \mathrm{C}\right)$ with green roof with TEVA blocks in relation to the highest surface temperature of the external face $\left(34.8^{\circ} \mathrm{C}\right)$ is highlighted here, remaining below the highest external $\left(30.8^{\circ} \mathrm{C}\right)$ and internal $\left(31.4^{\circ} \mathrm{C}\right)$ air temperatures of this prototype. This result is coherent with those achieved by other authors (VECCHIA [16]; ANDRADE e RORIZ [17]; MORAIS [18]; OULDBOUKHITINE et al. [15]).

The same phenomenon does not occur with the prototype with exposed slab, which presents little difference (only $0.6^{\circ} \mathrm{C}$ ) between the highest internal and external surface temperatures. In this comparison, the effect of the green roof with TEVA blocks in the reduction of the internal air and surface temperatures of the prototype is well characterized.

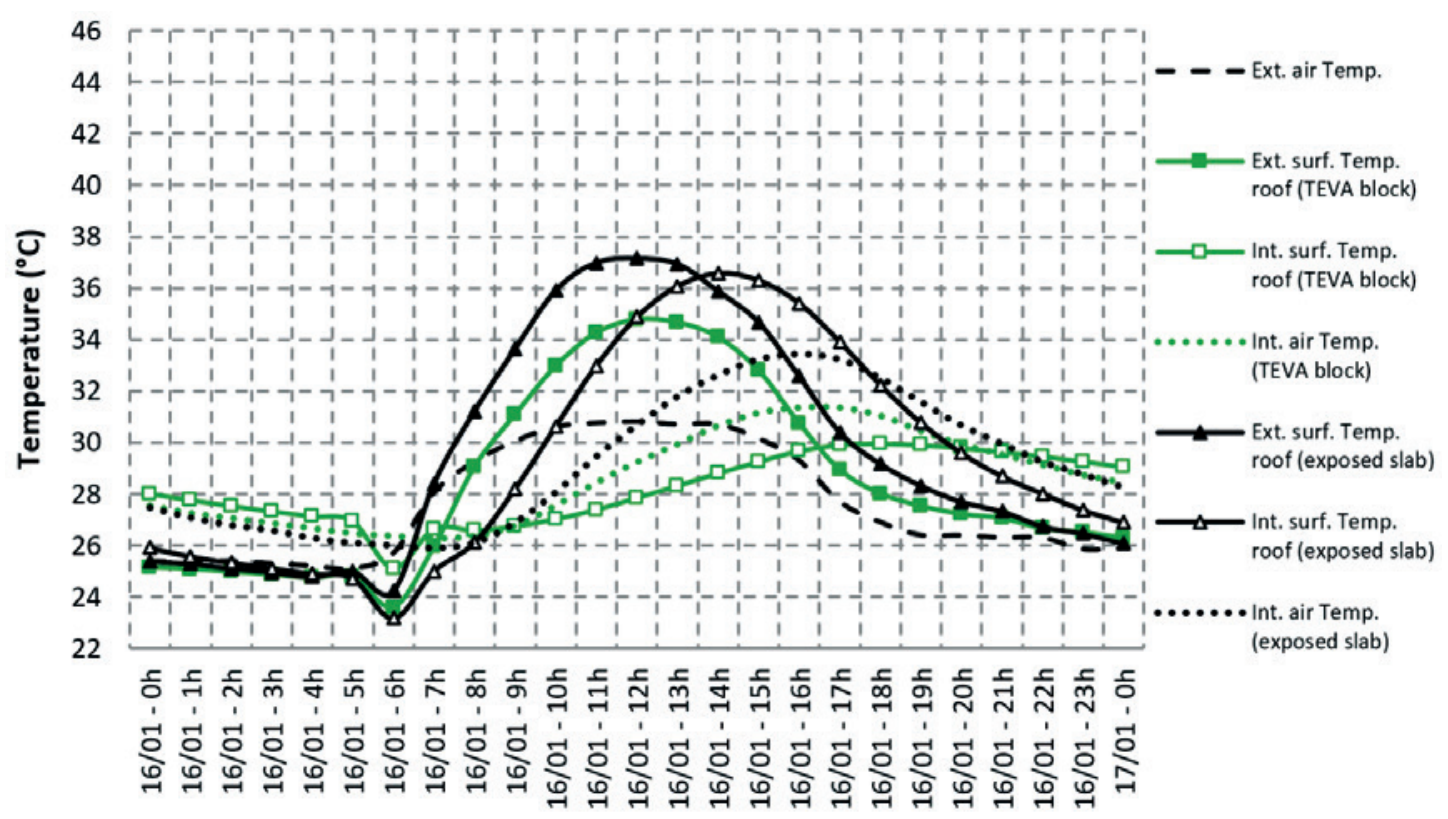

\section{Figure 7}

Thermal behavior of the prototype with green roof with TEVA blocks over the slab and of the prototype with exposed slab, on the typical summer day selected 


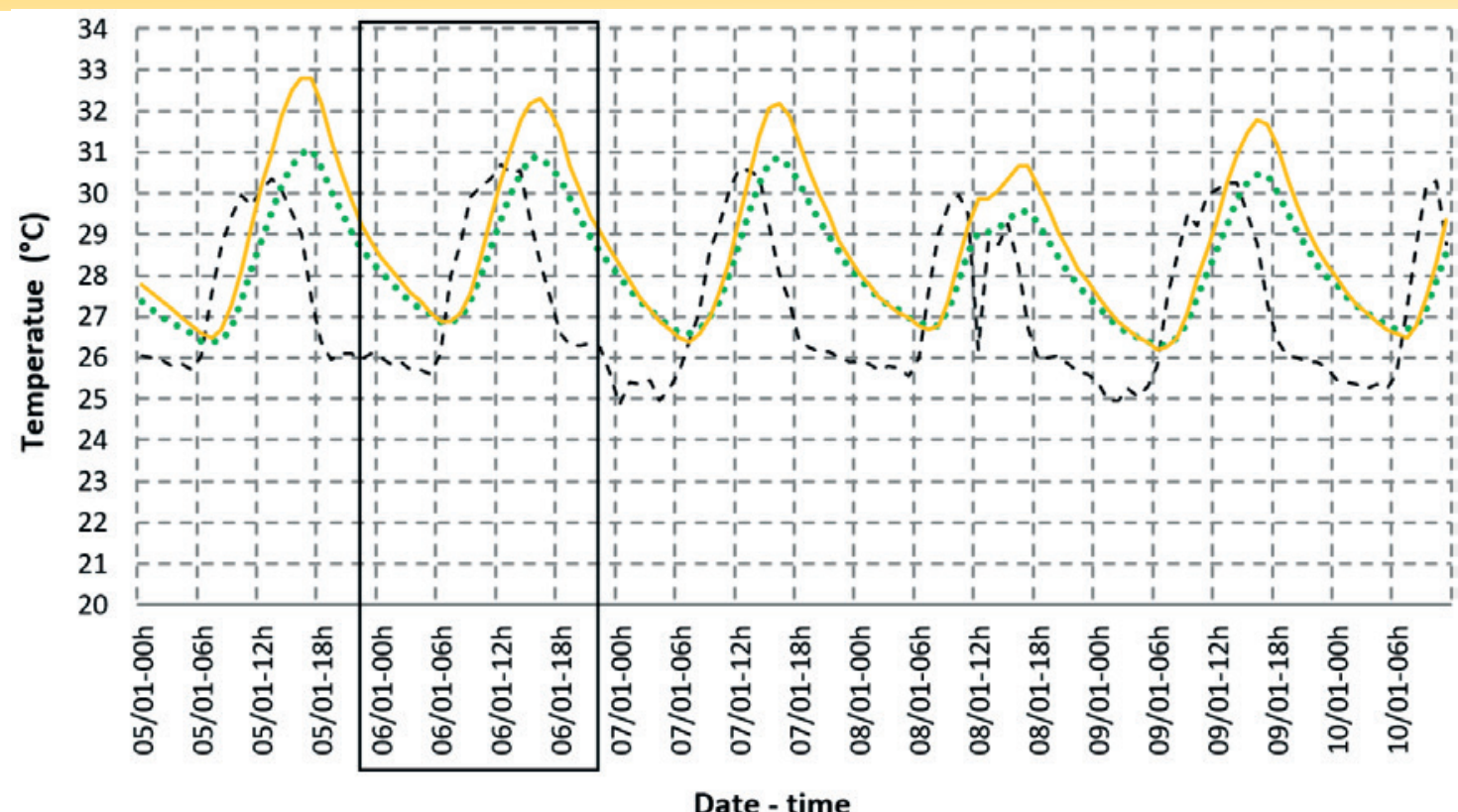

- - . Ext. Air Temp. ........ Int. Air Temp. (TEVA block) —Int. Air Temp. (fiber-cement roof tiles)

\section{Figure 8}

Records for the prototypes with fiber-cement roof tiles and with green roof with TEVA blocks

\subsubsection{Regarding the covering with fiber-cement roof tile on the slab}

For the characterization of the thermal behavior of the green roof with TEVA blocks regarding the covering with fiber-cement roof tiles, it is observed that for the comparison between the external air temperature and the internal air temperatures, for each prototype that was analyzed, the differences are again remarkable.
In the prototype with a fiber-cement roof tile cover, the internal air temperature is significantly more elevated than the same ones registered in the prototype with green roof with TEVA blocks cover, with the latter being very close to the external air temperature. This can be observed for the typical summer day that was analyzed (January 6, 2015) and for the other days of the week of measurements, according to what can be seen in Figure 8.

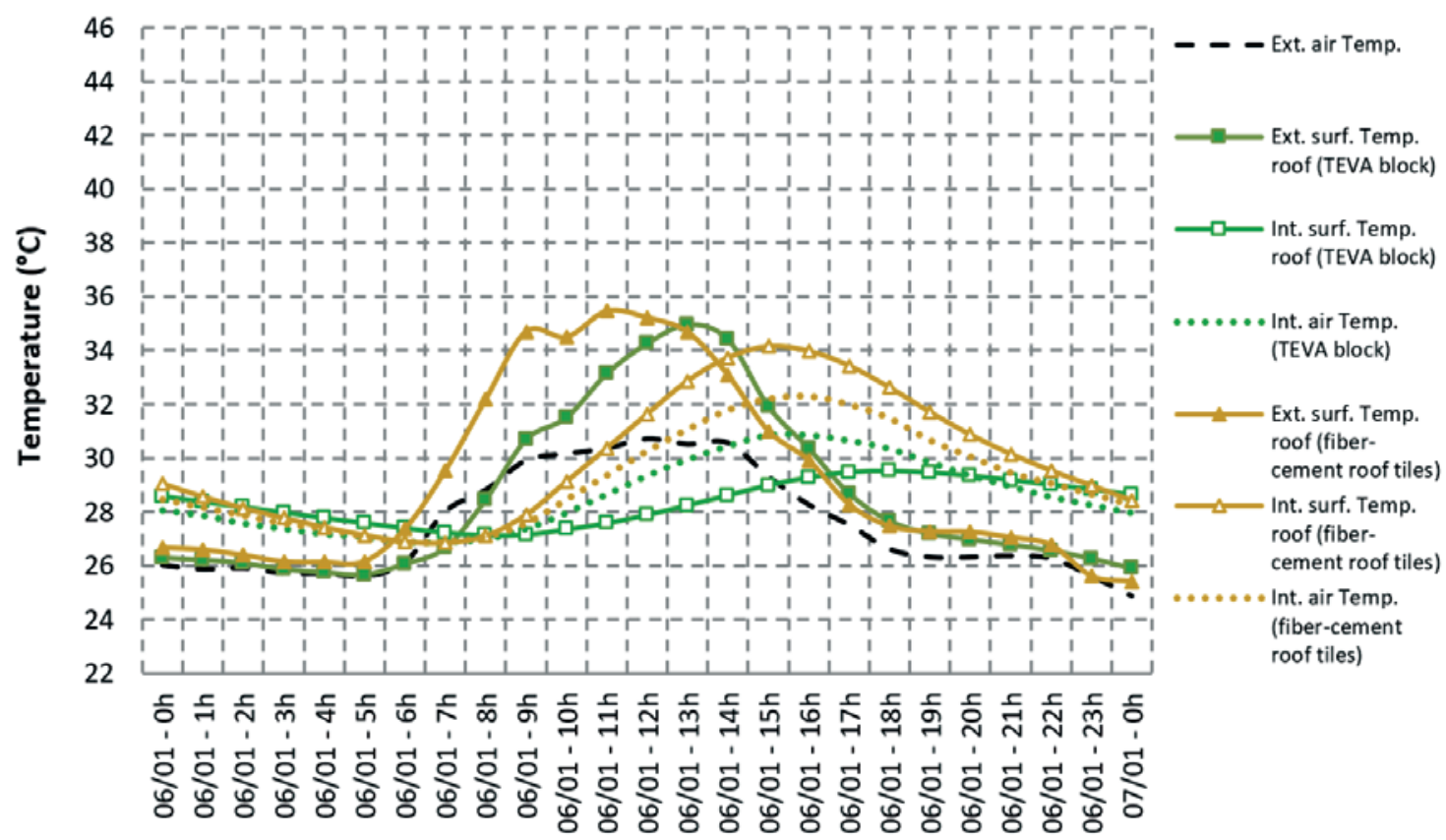

Date - time

\section{Figure 9}

Thermal behavior of the prototype with a green roof with TEVA blocks on the slab and of the prototype with fiber-cement roof tiles on the slab, on the chosen typical summer day 


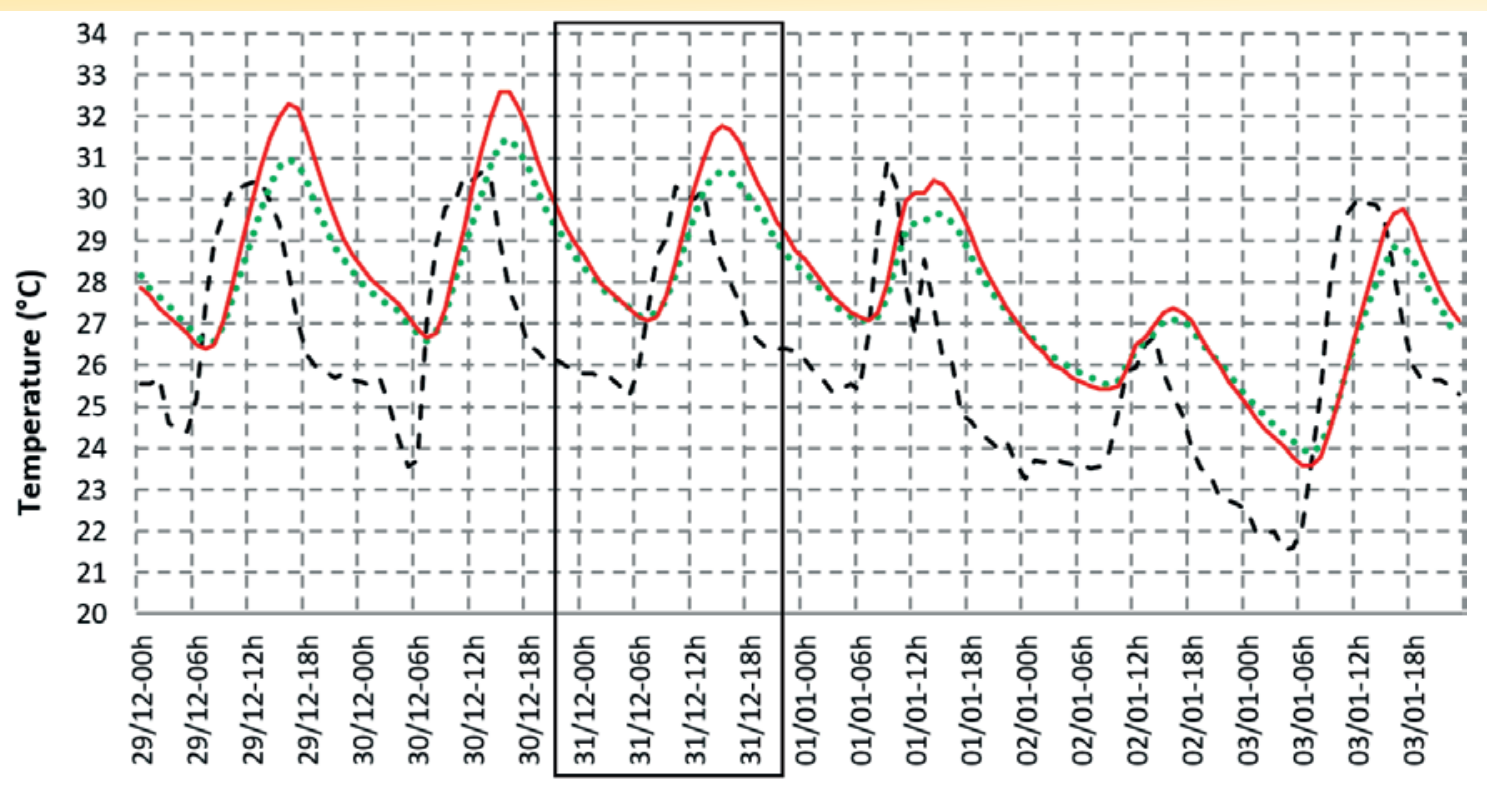

Date - time

- - - Ext. Air Temp. ....... Int. Air Temp. (TEVA block)

Int. Air Temp. (ceramic roof tiles)

\section{Figure 10}

Records for the prototypes with ceramic roof tiles and with green roof with TEVA blocks

Figure 9 presents the thermal behavior of both prototypes with different coverings, gathering all the records of temperatures that were analyzed. Once again, as expected, the internal surface temperatures of the roof of the prototype with a green roof with TEVA blocks remain lower during practically the whole daytime period and part of the night time period, when compared to the internal surface temperatures of the roof of the prototype with fiber-cement roof tiles on the slab. The same behavior can be observed in the comparison between the internal air temperatures of both prototypes, but in this case, such temperatures remain lower for the prototype with green roof, during the whole time (day and night), resulting in lower temperature ranges. From these results, it is confirmed that the biggest reduction in internal air temperatures occur in the prototype with a green roof with TEVA blocks, especially during the period of highest solar irradiation. This behavior is similar to the one observed during the previous comparison, which confirms

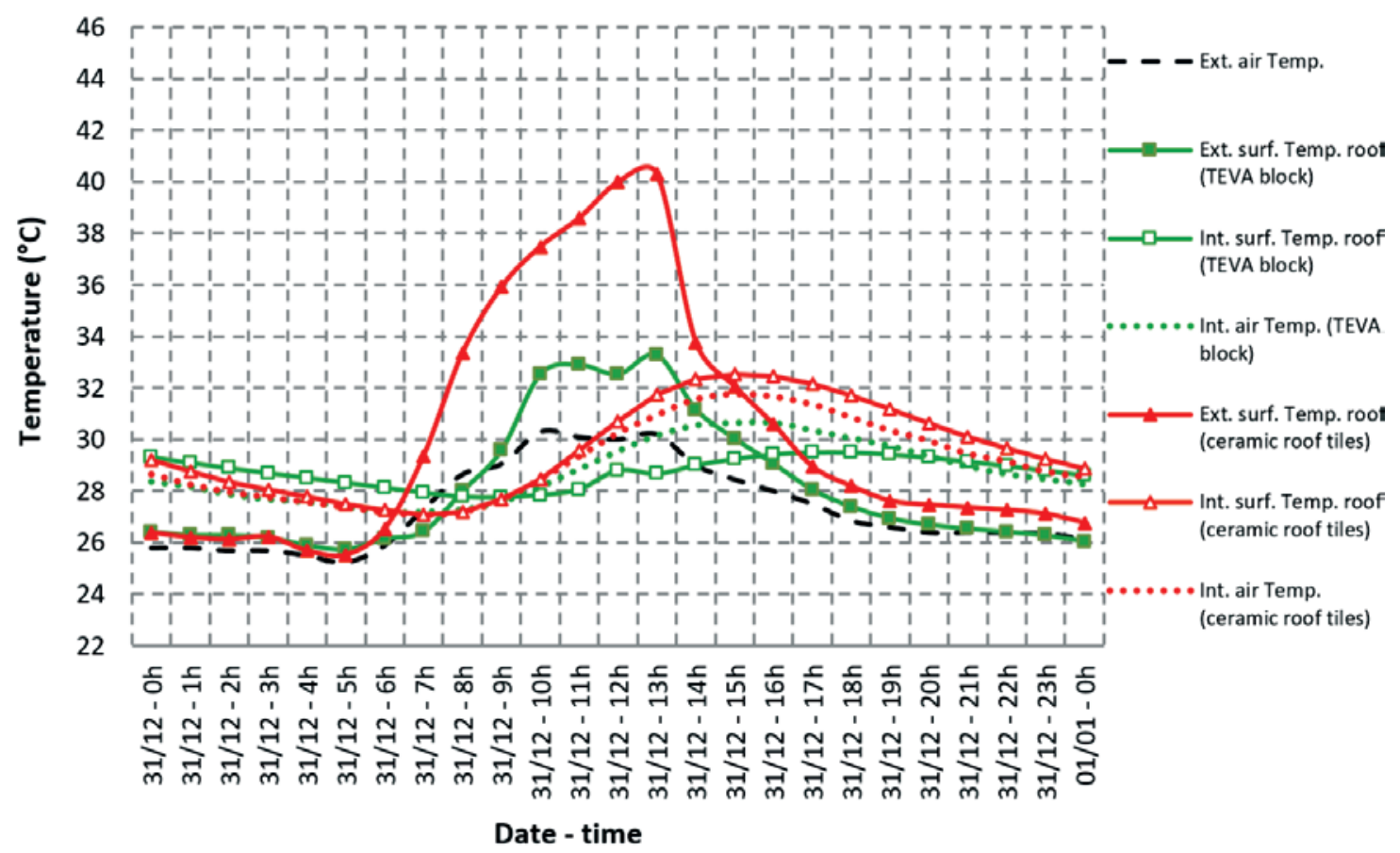

Figure 11

Thermal behavior of the prototype with the green roof with TEVA blocks on the slab and of the prototype with ceramic roof tiles on the slab, on the selected typical summer day 


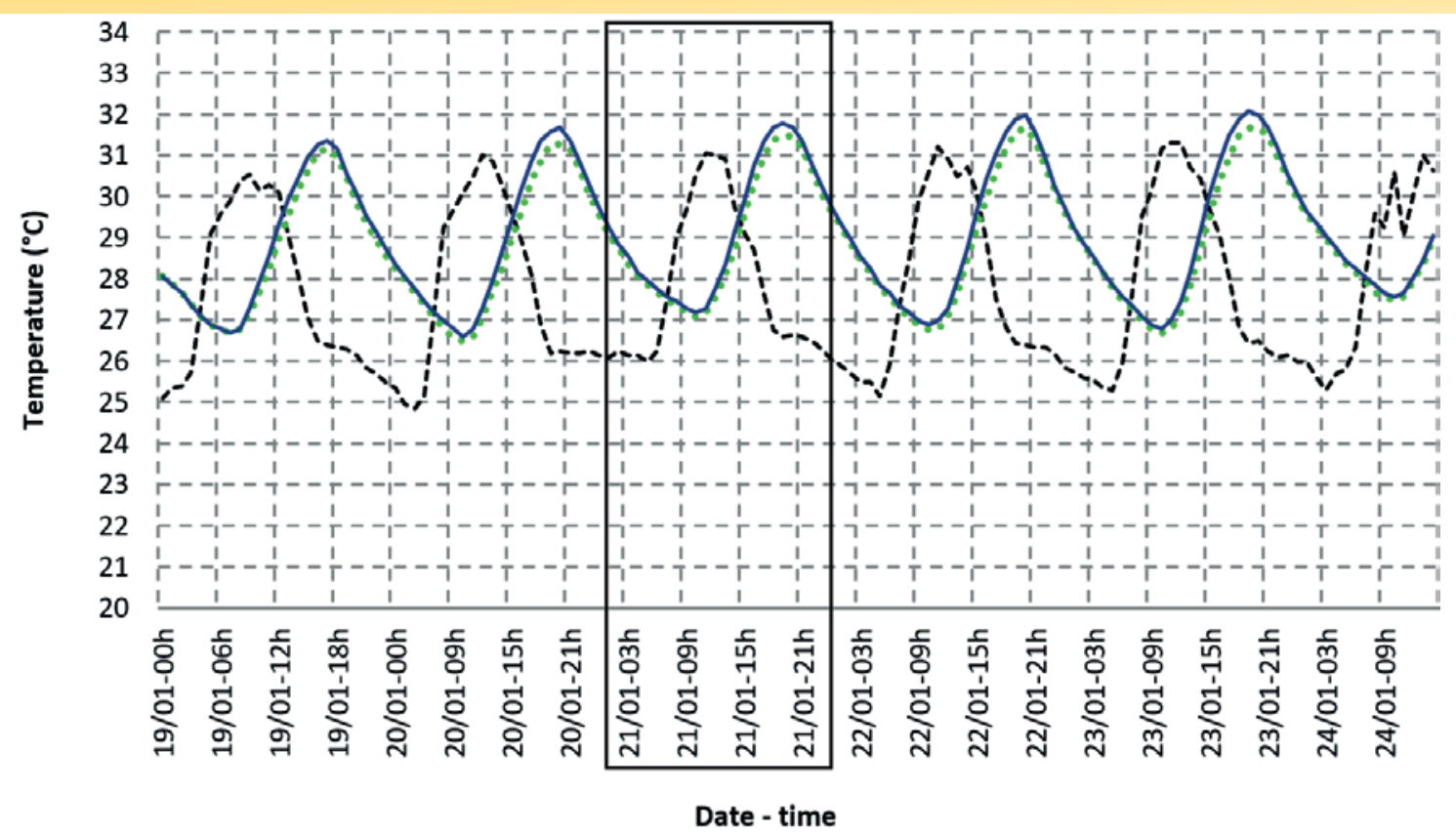

Ext. Air Temp.

- Int. Air Temp. (TEVA block)

Int. Air Temp. (concrete block)

Figure 12

Comparison between the prototypes with green roofs with concrete blocks and with TEVA blocks

the capacity of the proposed green roof with TEVA blocks of reducing the internal surface and air temperatures of the prototype.

\subsubsection{Regarding the ceramic roof tile covering on the slab}

The characterization of the thermal behavior of the green roof with TEVA blocks regarding the ceramic roof tile covering is discussed based on the records presented in Figure 10. The internal air temperature of the prototype with a green roof with TEVA blocks was lower for the typical summer day (December 31, 2014) and during the whole week of measurements (except for January 02, 2015), when compared to the prototype with a ceramic roof tile covering. Practically, the same thermal delay (5 hours) in relation to the external air temperature is characterized for both prototypes. The records made on January 02, 2015 are atypical, with lower highest internal air temperatures, which are also very similar between both prototypes. Actually, on this day there was a higher precipitation (rainfall) over the analyzed prototypes, which can justify the result, considering the characteristic of the ceramic material (of the roof tiles), that certainly absorbs a lot of humidity during the rain. Therefore, this can be an additional contributing factor for the reduction of the internal air temperatures of this prototype, during this specific day of measurements. The absorption of humidity by the green roof must also favor the lowering of the internal air temperature. The evaporative cooling of both the ceramic roof tiles and the vegetated TEVA blocks coverings, on the respective slabs of the prototypes, results in similar thermal behaviors for both types of coverings during this atypical day.

In Figure 11, it is observed that the internal surface temperatures of the roof of the prototype with a green roof with TEVA blocks are lower during the whole period between 9 a.m. and midnight, when compared to the internal surface temperatures of the roof of the prototype with ceramic roof tile. According to what has been observed in both previous cases, only on the records for the prototype with a green roof with TEVA blocks it is verified that its internal air temperature remains higher than the internal surface temperature of the roof itself, during most of the day (morning and afternoon), which corresponds to the period of highest solar irradiation on the covering. In this case, it is important to highlight the smaller contribution of the covering for the increase of the internal air temperature of the prototype, only when the green roof with EVA blocks is present. In the comparison between the internal air temperatures of both prototypes that were analyzed (green roof with TEVA blocks $X$ ceramic roof tiles) it is noticed again that the lower temperature is for the prototype with the green roof with TEVA blocks, which results in lower temperature ranges. Once again, this confirms the capacity of this type of proposed green roof to lower the internal temperatures.

\subsection{Comparison between green roofs:" concrete blocks versus TEVA blocks}

In Figure 12, it can be seen that the internal air temperature of the prototype with a green roof with TEVA blocks is always slightly lower when compared to the prototype with a green roof with concrete blocks, including the temperature for the typical summer day (January 21, 2015). Considering that the only difference between both green roofs that were compared is the presence of EVA waste in the TEVA blocks, the additional contribution for the thermal insulation of the green roof proposed with this component can be confirmed here. It can also be noticed how the highest internal and external air temperatures of the prototypes present very close values, unlike the previous analysis of the comparison with the conventional roofs (exposed slab, fiber-cement roof tile on the slab and ceramics roof tile on the slab).

It is noticed here that there are also slight differences between the results obtained from both prototypes for the other temperature records. In fact, in Figure 13, it is noticeable that both green roofs, with TEVA blocks and with concrete blocks, present similar highest internal air temperatures $\left(31.5^{\circ} \mathrm{C}\right.$ and $\left.31.8^{\circ} \mathrm{C}\right)$ and they are very close to the highest external air temperature $\left(31.1^{\circ} \mathrm{C}\right)$, with highlight for the thermal delays of 5 hours. However, only the green 
roof with TEVA blocks is able to maintain the internal surface temperature of the roof lower (approximately $1^{\circ} \mathrm{C}$ ) when compared to the internal air temperature, between 9 a.m. and 7 p.m., which is a very interesting differentiation in the thermal characterization of the TEVA block. This way, the additional contribution of the EVA aggregates (waste from the footwear industry) is well evidenced for the effects on the proposed green roof with TEVA blocks for the expected improvement of the thermal behavior of this prototype's covering.

Regardless, the differences between both green roofs that were compared are considered small, with the determining factor for their thermal behavior being the presence of the substrate and of the vegetation in similar conditions. The blocks, as modules with the same geometry to receive the vegetation, according to what was proposed here, give their contribution, certainly smaller, as the factors that seem to interfere more in the thermal behavior of the green roof seem to be related to the organic part of the system, in other words, the height of the substrate and how much the vegetation densifies. In this case, it is suitable to remember that there is practically no difference between the highlighted variables (substrate's height and vegetation's type of densification in the interior of blocks) in the comparative analysis of the green roofs with TEVA and with concrete blocks that was carried out.

Therefore, despite the slight differences found between both types of green roof that were compared, the identification of the additional contribution of the EVA waste, as a light aggregate present in the TEVA blocks, which favored an additional lowering of the thermal load to the interior of the prototype, can be conclusive.

\subsection{Analysis of the temperature ranges for the surface temperatures of the roofs}

Table 2 presents data related to the temperature ranges for the internal and external surface temperatures of each evaluated prototype's roof. As it can be noticed, the temperature ranges, consider- ing the surface temperatures for the prototype with exposed slab, both in the external $\left(12.9^{\circ} \mathrm{C}\right)$ and internal $\left(13.4^{\circ} \mathrm{C}\right)$ environments are very high and similar. In relation to the prototype with green roof with TEVA blocks, these temperature ranges are significantly different, when the external and internal surfaces are compared. The external temperature range $\left(11.1^{\circ} \mathrm{C}\right)$ is close to what was obtained for the exposed slab, however the great difference is found in the analysis for the internal environment, with the temperature range of the prototype with the green roof with TEVA blocks, which is reduced to less than half $\left(4.8^{\circ} \mathrm{C}\right)$. The significant reduction of the highest surface temperature of the internal face of the roof $\left(6.6^{\circ} \mathrm{C}\right)$ is highlighted, when both prototypes - green roof with TEVA blocks and exposed slab - are compared.

On the other hand, in regards to the lowest internal surface temperatures, it is verified that they are similar, between $23.1^{\circ} \mathrm{C}$ and $25.1^{\circ} \mathrm{C}$, for both prototypes, but the highest value is observed in the prototype with the green roof with TEVA blocks. This behavior is justified by the higher inertia of the green roof, since if on the one hand this roof reduces the surface temperature peak on the internal face of the roof of the prototype during the day, on the other hand, it hampers the reduction of the low temperature on this same face of the roof during the night, resulting in lower temperature ranges. The results obtained in other studies (MORAIS [18]; VECCHIA [16]; ANDRADE e RORIZ [17]) corroborate the behavior that was highlighted here.

In relation to the temperature ranges calculated from the surface temperature of the roof on its different faces (internal and external) of the covering of the prototypes that were compared, it is noticed that the values are similar for the green roof with TEVA blocks and for the fiber-cement roof $\left(9.3^{\circ} \mathrm{C}\right.$ and $\left.10.0^{\circ} \mathrm{C}\right)$, considering the external records, which does not happen when the temperature ranges for the internal surface temperatures are compared. As for the green roof with TEVA blocks its value $\left(2.3^{\circ} \mathrm{C}\right)$ is practically $1 / 3$ of what was verified for the covering with fiber-cement roof tiles on the slab $(7.3$ ${ }^{\circ} \mathrm{C}$ ). It is also observed that the temperature range of the prototype

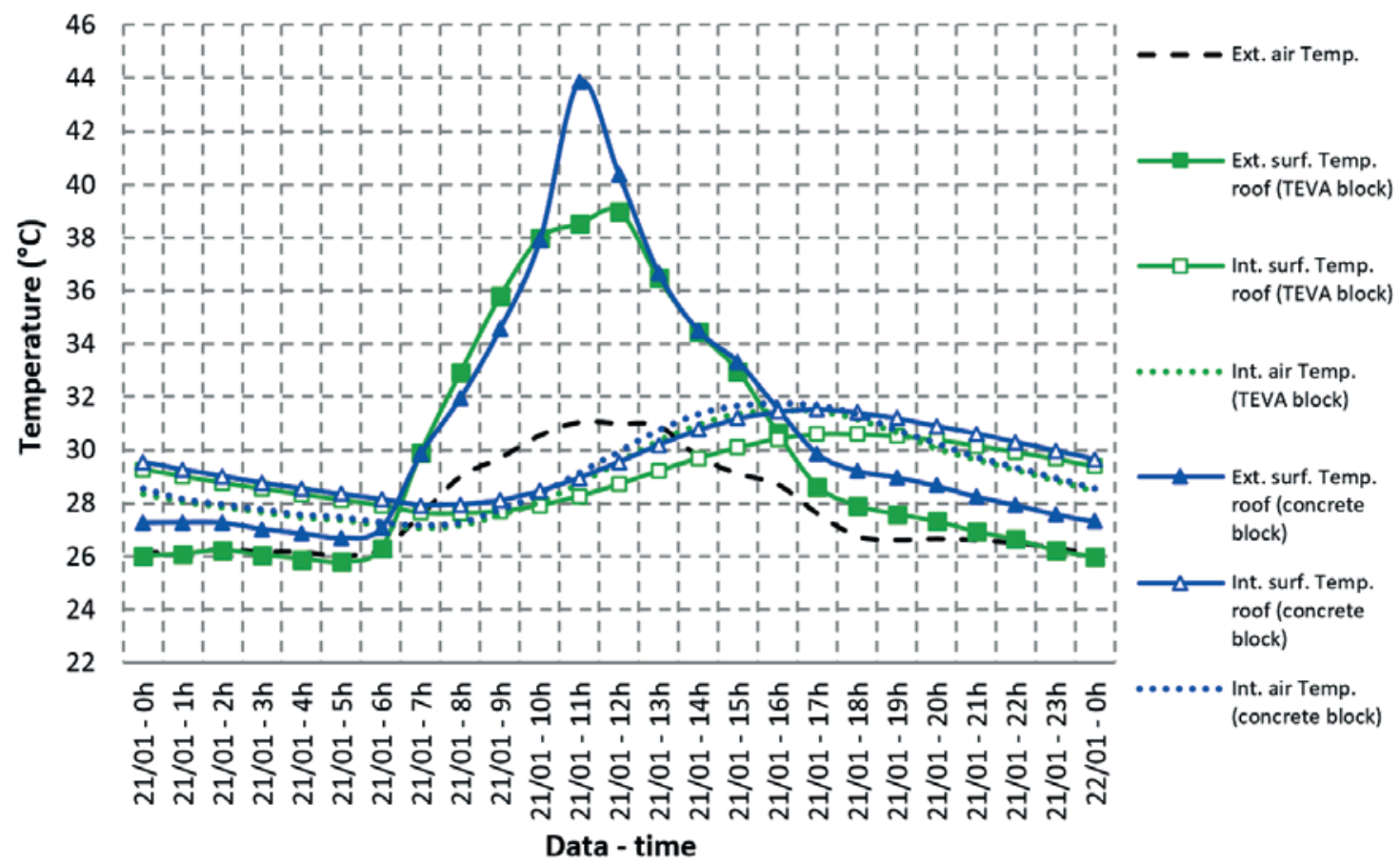

Figure 13

Comparative thermal behavior between the prototype with a green roof with TEVA blocks on the slab and the prototype with a green roof with concrete blocks on the slab, on the selected typical summer day 
Table 2

Temperature ranges for the internal and external surface temperatures of the roofs of the prototypes

\begin{tabular}{|c|c|c|c|}
\hline \multirow{2}{*}{\multicolumn{2}{|c|}{$\begin{array}{l}\text { Surface temperatures } \\
\text { prototypes roof }\left({ }^{\circ} \mathrm{C}\right)\end{array}$}} & \multicolumn{2}{|c|}{ Measurements for typical summer day: 16-01-2015 } \\
\hline & & \multirow{2}{*}{$\begin{array}{c}\begin{array}{c}\text { Extensive modular green } \\
\text { roof TEVA blocks }\end{array} \\
34,7\end{array}$} & \multirow{2}{*}{$\frac{\text { Exposed slab }}{37,1}$} \\
\hline \multirow{3}{*}{ External } & Temperature maximum & & \\
\hline & Temperature range & 11,1 & 12,9 \\
\hline & Temperature minimum & 23,5 & 24,2 \\
\hline \multirow{3}{*}{ Internal } & Temperature maximum & 29,9 & 36,5 \\
\hline & Temperature range & 4,8 & 13,4 \\
\hline & Temperature minimum & 25,1 & 23,1 \\
\hline
\end{tabular}

\begin{tabular}{|c|c|c|c|}
\hline \multirow{2}{*}{\multicolumn{2}{|c|}{$\begin{array}{l}\text { Surface temperatures } \\
\text { prototypes roof }\left({ }^{\circ} \mathrm{C}\right)\end{array}$}} & \multicolumn{2}{|c|}{ Measurements for typical summer day: 06-01-2015 } \\
\hline & & $\begin{array}{l}\text { Extensive modular green } \\
\text { roof TEVA blocks }\end{array}$ & Fiber-cement roof tiles \\
\hline \multirow{3}{*}{ External } & Temperature maximum & 34,9 & 35,4 \\
\hline & Temperature range & 9,3 & 10,0 \\
\hline & Temperature minimum & 25,6 & 25,4 \\
\hline \multirow{3}{*}{ Internal } & Temperature maximum & 29,5 & 34,1 \\
\hline & Temperature range & 2,3 & 7,3 \\
\hline & Temperature minimum & 27,1 & 26,8 \\
\hline
\end{tabular}

\begin{tabular}{|c|c|c|c|}
\hline \multirow{2}{*}{\multicolumn{2}{|c|}{$\begin{array}{l}\text { Surface temperatures } \\
\text { prototypes roof }\left({ }^{\circ} \mathrm{C}\right)\end{array}$}} & \multicolumn{2}{|c|}{ Measurements for typical summer day: $31-12-2014$} \\
\hline & & \multirow{2}{*}{$\begin{array}{c}\begin{array}{c}\text { Extensive modular green } \\
\text { roof TEVA blocks }\end{array} \\
33,2\end{array}$} & \multirow{2}{*}{$\begin{array}{c}\text { Ceramic roof tile } \\
40,2\end{array}$} \\
\hline \multirow{3}{*}{ External } & Temperature maximum & & \\
\hline & Temperature range & 7,5 & 14,7 \\
\hline & Temperature minimum & 25,7 & 25,5 \\
\hline \multirow{3}{*}{ Internal } & Temperature maximum & 29,5 & 32,5 \\
\hline & Temperature range & 1,7 & 5,4 \\
\hline & Temperature minimum & 27,7 & 27,0 \\
\hline
\end{tabular}

\begin{tabular}{|c|c|c|c|}
\hline \multirow{2}{*}{\multicolumn{2}{|c|}{$\begin{array}{l}\text { Surface temperatures } \\
\text { prototypes roof }\left({ }^{\circ} \mathrm{C}\right)\end{array}$}} & \multicolumn{2}{|c|}{ Measurements for typical summer day: 21-01-2015 } \\
\hline & & \multirow{2}{*}{$\begin{array}{c}\begin{array}{c}\text { Extensive modular green } \\
\text { roof TEVA blocks }\end{array} \\
38,9 \\
\end{array}$} & \multirow{2}{*}{$\begin{array}{c}\begin{array}{c}\text { Extensive modular green roof } \\
\text { concrete blocks }\end{array} \\
43,8 \\
\end{array}$} \\
\hline \multirow{3}{*}{ External } & Temperature maximum & & \\
\hline & Temperature range & 13,2 & 17,1 \\
\hline & Temperature minimum & 25,7 & 26,7 \\
\hline \multirow{3}{*}{ Internal } & Temperature maximum & 30,6 & 31,5 \\
\hline & Temperature range & 2,9 & 3,6 \\
\hline & Temperature minimum & 27,6 & 27,9 \\
\hline
\end{tabular}


with the green roof with TEVA blocks, considering the records for the internal and external surface temperatures, is around $75 \%$ lower for the internal environment, which confirms the capacity of this type of green roof to lower the internal temperatures. Just as it happened in the previous case the lowest internal surface temperature (27.1 ${ }^{\circ} \mathrm{C}$ ) remains higher for the prototype with the green roof with TEVA blocks. Again, the effect of the higher thermal inertia for the green roof is confirmed, being characterized by the lower and higher values for the highest and lowest surface temperatures, respectively, on the internal face of the prototype's roof.

Differently from both previous cases, the temperature ranges related to the surface temperatures, in relation to both external and internal environments, were very different and a lot lower for the prototype with the green roof with TEVA blocks, when compared to the prototype with the ceramic roof. For the typical summer day (December 31, 2014), the prototype with the ceramic roof tiles covering on the slab presented a very high external surface temperature $\left(40.2^{\circ} \mathrm{C}\right)$, which resulted in a higher temperature range $\left(14.7^{\circ} \mathrm{C}\right)$. On the other hand, the same temperature range for the prototype with the green roof with EVA blocks was around half of that $\left(7.5^{\circ} \mathrm{C}\right)$. It is also noted that there is a higher reduction in temperature range of the surface temperature in the internal face of the roof, when both prototypes are compared, with the green roof with TEVA blocks having the lowest value $\left(1.7^{\circ} \mathrm{C}\right)$. Certainly, this behavior also contributes for the larger reduction of the internal air temperature of this prototype, which is more notable during the day with higher solar irradiation.

It can also be observed that only for the prototype with the green roof with TEVA blocks it is possible to record a high internal surface temperature of the roof that is lower than $30^{\circ} \mathrm{C}$, when compared to the three other prototypes: exposed slab, fiber-cement roof tiles over the slab and ceramic roof tiles over the slab. On the other hand, like the previous comparisons, the green roof keeps the internal lowest surface temperature on the roof slightly higher, which confirms the effect of its higher thermal inertia.

Lastly, it can be seen that the temperature ranges related to the internal surface temperatures of both different types of green roofs are very close to each other $\left(2.9^{\circ} \mathrm{C}\right.$ and $3.6^{\circ} \mathrm{C}$, if compared to the results from other types of covering (previous cases). However, the surface temperatures, highest and lowest, in the internal and external environments of the prototypes are always lower for the green roof with TEVA blocks covering, which also always results in lower temperature ranges for this type of covering. It is worth mentioning that in the present study, this phenomenon is only identified in this comparison between both green roofs. This reinforces the evidence of the contribution of the only variable under analysis, which is the presence of the EVA aggregates (waste from the footwear industry) in the TEVA blocks, which received the vegetation. Thus, this result also confirms the effects of the presence of the EVA aggregate in the TEVA block used in the green roof, improving the thermal behavior in the internal environment of the prototype.

\section{Conclusions}

Considering the measurement conditions in the compared prototypes and the analysis of the results for the typical summer day, in a hot and humid climate, it can be concluded that:
- The conventional coverings (exposed slab, fiber-cement roof tiles on the slab and ceramics on the slab) in the evaluated prototypes were responsible for maintaining the internal air temperatures between $1{ }^{\circ} \mathrm{C}$ and $2{ }^{\circ} \mathrm{C}$ higher when compared to the prototype with the proposed green roof with TEVA blocks;

- The green roof with TEVA blocks system, when compared to the conventional coverings, also enabled a higher surface temperature reduction on the roof, in the internal environment of the prototype, characterizing the lowest temperature ranges, the highest thermal delays and the highest thermal inertias;

- The green roof with TEVA blocks covering was notable for presenting a surface temperature of the roof that was lower than the internal air temperature of the evaluated prototype.

Such conclusions corroborate the thermal behavior of the proposed green roof, characterizing its capacity for insulation, which is coherent with the lower thermal transmittance and higher thermal resistance of this covering system, when compared to the conventional ones.

By making the comparison between prototypes with the same green roof, but executed with different types of blocks (TEVA blocks $x$ concrete blocks), it is possible to conclude that:

With the use of the TEVA block, the temperatures (highest and lowest) and temperature ranges were lower, which shows the effect of the only variable under analysis, the presence of the EVA waste;

- The presence of the EVA waste in the TEVA blocks enabled that additional reduction, of approximately $1{ }^{\circ} \mathrm{C}$, in the highest internal surface temperature of the prototype in relation to the highest air temperature in the interior of the prototype.

Therefore, the present study made it possible to prove that the presence of EVA aggregates, that come from the footwear industry waste, in the TEVA blocks, additionally contributes for the reduction of the internal (air and surface) temperatures of the environment under the green roof. This is very useful to add quality to the built environment and value to the recycling process of the EVA waste, in the manufacturing of new re-usable products in the civil construction. Beyond this aspect, it is highlighted that the proposal of the extensive modular green roof system with TEVA blocks has the potential for an alternative destination for the waste from the footwear industry.

\section{Acknowledgments}

To the CAPES for the partial financing of the present research; to the NUPPA-UFPB for providing the space for the construction of the prototypes; to the Technology Center Labs (especially LABEME) of the Institution (UFPB), for the support given for the execution of this research.

\section{References}

[1] BERARDI, Umberto; GHAFFARIANHOSEINI, AmirHosein; GHAFFARIANHOSEINI, Ali. State-of-the-art analysis of the environmental benefits of green roofs. Applied Energy, Vol. 115, pp. 411-428, 2014.

[2] BIANCHINI, F., HEWAGE, K. How "green" are the green 
roofs? Lifecycle analysis of green roof materials. Building and environment, Vol. 48, pp. 57-65, 2012.

[3] ZATTERA, A. J.; BIANCHI, O.; ZENI, M. ;FERREIRA, C. A. Caracterização de Resíduos de Copolímeros de Etileno-Acetato de Vinila - EVA. Polímeros: Ciência e Tecnologia, Vol. 15, n 1, pp. 73-78, 2005.

[4] GARLET, G. Aproveitamento de resíduos de EVA (Ethylene Vinyl Acetate) como agregado para concreto leve na construção civil. Dissertação de Mestrado, Universidade Federal do Rio Grande do Sul-UFRGS, Porto Alegre-RS, 1998.

[5] BEZERRA, A. J. V. Utilização do resíduo da indústria de calçados (EVA - Etileno Acetato de Vinila) como agregado leve na produção de blocos vazados de concreto para alvenaria sem função estrutural. 115p. Dissertação de Mestrado, Universidade Federal da Paraíba, Campina Grande-PB, 2002.

[6] HAX, S.P.P. Estudo do potencial dos resíduos de E.V.A. no isolamento de ruído de impacto nas edificações. Dissertação de Mestrado, Universidade Federal de Santa MariaUFSM, Santa Maria-RS, 2002.

[7] POLARI FILHO, R. S. Contribuição ao processo de reciclagem dos resíduos da indústria de calçados na construção civil: bloco EVA uma alternativa às alvenarias das construções. Dissertação de Mestrado, Universidade Federal da Paraíba-UFPB, João Pessoa-PB, 2005.

[8] ROCHA, F. M. D. Aproveitamento de resíduos sólidos industriais em materiais alternativos na perspectiva da construção seca: bloco EVA - intertravamento e racionalização das alvenarias. Dissertação de Mestrado, Universidade Federal da Paraíba-UFPB, João Pessoa-PB, 2008.

[9] MELO, A. B., LIMA FILHO, M. R. F. Avaliação de desempenho estrutural de protótipo com paredes construídas com blocos EVA. Ambiente Construído, Vol. 9, n4, pp. 141-155, Out/Dez. 2009.

[10] SANTOS, F. A. Avaliação de placas cimentícias com resíduo de EVA quanto ao seu nível de isolamento acústico em sistemas de pisos flutuantes. Dissertação de Mestrado, Universidade Federal da Paraíba-UFPB, João Pessoa-PB, 2013.

[11] TUTIKAN, B.F; NUNES, M.F.O; LEAL, L.C.; MARQUETTO, L. Hormigón ligero con agregado reciclado de EVA para atenuación del ruido de impacto (Lightweight concrete with EVA recycled aggregate for impact noise attenuation). Materiales de Construcción, Vol. 63, pp. 309-316, 2013.

[12] CASTLETON, H.F.; STOVIN, V.; BECK, S.B.M.; DAVISON, J.B. Green roofs; Building energy savings and the potential for retrofit. Energy and Buildings, Vol. 42, pp. 1582-1591. 2010.

[13] JAFFAL, I.; OULDBOUKHITINE, S.; BELARBI R. A comprehensive study of the impact of green roofs on building energy performance. Renewable Energy, Vol. 43, pp. 157-164, 2012.

[14] DEL BARRIO, E. P. Analysis of the green roofs cooling potential in buildings. Energy and Buildings, Vol. 27, pp. 179193, 1998.

[15] OULDBOUKHITINE, S.; BELARBI, R.; JAFFAL, I.; TRABEL$\mathrm{SI}, \mathrm{A}$. Assessment of green roof thermal behavior: A coupled heat and mass transfer mode. Building and Environment Vol. 46, pp. 2624-2631, 2011.

[16] VECCHIA, F. (2005). Cobertura Verde Leve (CVL): Ensaio Experimental. In: VI Encontro Nacional de Conforto no
Ambiente Construído (ENCAC) e IV Encontro Latino-americano sobre Conforto no Ambiente Construído (ELACAC), Maceió, Alagoas, Brasil, 2005.

[17] ANDRADE, N. C.; RORIZ, M. Comportamento térmico de cobertura verde utilizando a grama Brachiaria Humidicola na cidade de São Carlos, SP. In: X Encontro Nacional de Conforto no Ambiente Construído e VI Encontro Latino-americano de Conforto no Ambiente Construído, Natal- RN, Brasil, 2009.

[18] MORAIS, C. S. Desempenho térmico de coberturas vegetais em edificações na cidade de São Carlos- SP. Dissertação (Mestrado)- Universidade Federal de São Carlos-UFSCar, São Carlos-SP, 2004.

[19] ASSOCIAÇÃO BRASILEIRA DE NORMAS TÉCNICAS. NBR 15575-1: Edificações Habitacionais - Desempenho Parte 1: Requisitos gerais. Rio de Janeiro, 2013. 